Article

\title{
The Effect of Thermal Treatment on the Physicochemical Properties of Minerals Applied to Heterogeneous Catalytic Ozonation
}

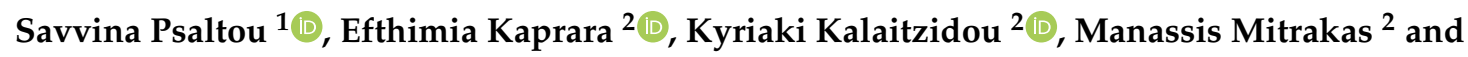 \\ Anastasios Zouboulis $1, *$ (D) \\ 1 Laboratory of Chemical and Environmental Technology, Department of Chemistry, Aristotle University, \\ 54124 Thessaloniki, Greece; spsaltou@chem.auth.gr \\ 2 Laboratory of Analytical Chemistry, Department of Chemical Engineering, Aristotle University, \\ 54214 Thessaloniki, Greece; kaprara@auth.gr (E.K.); kikalaitz@geo.auth.gr (K.K.); mmitraka@auth.gr (M.M.) \\ * Correspondence: zoubouli@chem.auth.gr
}

Received: 30 October 2020; Accepted: 14 December 2020; Published: 15 December 2020

check for updates

\begin{abstract}
In order to enhance the efficiency of heterogeneous catalytic ozonation, the effect of thermal treatment on three commonly used and inexpensive minerals, i.e., zeolite, talc and kaolin (clay), which present different physicochemical properties as potential catalysts, has been examined for the removal of para-chlorobenzoic acid (p-CBA). p-CBA is considered a typical micro-pollutant, usually serving as an indicator (model compound) to evaluate the production of hydroxyl radicals in ozonation systems. The catalytic activity of selected solid catalysts was studied for different $\mathrm{pH}$ values $(6,7$ and 8$)$ and different temperatures $\left(15^{\circ} \mathrm{C}, 25^{\circ} \mathrm{C}\right.$ and $\left.35^{\circ} \mathrm{C}\right)$. The mechanism of radicals production was also verified by the addition of tert-butyl alcohol (TBA). The respective thermal behavior study showed that the point of zero charge (PZC) of these minerals increased with the increase of applied treatment temperature, as it removed crystalline water and hydroxyls, thus improving their hydrophobicity. Circa-neutral surface charge and the presence of hydrophobicity were found to favor the affinity of ozone with solid/catalytic surfaces and the subsequent production of hydroxyl radicals. Therefore, zeolite and talc, presenting PZC 7.2 and 6.5 respectively, showed higher catalytic activity after thermal treatment, while kaolin with PZC equal to 3.1 showed zero to moderate catalytic efficiency. The degradation level of p-CBA by oxidation was favored at $25^{\circ} \mathrm{C}$, while the $\mathrm{pH}$ value exerted positive effects when it was increased up to 8 .
\end{abstract}

Keywords: heterogeneous catalytic ozonation; PZC; p-CBA; minerals; thermal treatment; micropollutants removal

\section{Introduction}

Nowadays, persistent organic compounds (POPs)are considered chemical compounds of great environmental concern [1]. Several classes of them occur in aquatic ecosystems [2] but with rather low concentrations, ranging from $n g / L-\mu g / L$ (they are thus termed as micropollutants). They are very stable compounds and cannot be easily degraded or removed by the application of conventional biological wastewater treatment technologies [1]. Although their quantities are still quite low, they can constantly accumulate in fragile ecosystems, and there is a high probability of side effects in living organisms throughout the food chain [2]. Municipal wastewater treatment plants have been identified as one of the main sources of pollution from micropollutants. The treated wastewaters may contain several compounds of emerging concern, released into water bodies and eventually ending up in marine environments [3]. 
Among the available degradation techniques that have been examined for the removal/oxidation/destruction of micropollutants is the process of ozonation. This treatment method is based on the oxidation of organic compounds through the presence of ozone molecules, as well as through the secondary formation of hydroxyl radicals. Hydroxyl radicals are produced in this case by ozone self-decomposition and present higher oxidative potential than the application of single ozonation. Additionally, their ability to react unselectively with different organic molecules makes them an (almost) ideal oxidizing agent for Advanced Oxidation Processes (AOPs). However, in order to further increase the efficiency of this oxidation system, it is important to accelerate the production of hydroxyl radicals. The addition of an appropriate catalyst can enhance ozone decomposition, leading to a catalytic ozonation process, which is a promising treatment technique for the removal of refractory organic compounds, such as micropollutants, from water and wastewater sources. In heterogeneous catalytic ozonation, appropriate solid materials are commonly used as catalysts, improving hydroxyl radical's production [4].

In this procedure, the effective contact between ozone molecules and the catalyst surface is very important, and to some extent it can be estimated by the respective Point-of-Zero-Charge (PZC) of the solid material [5]. PZC is generally described as the $\mathrm{pH}$, where the net charge of the particle surface is equal to zero [6]. The overall charge of hydroxyl groups on the surface of a solid is responsible for the adsorption and subsequent decomposition of ozone. Hydroxyl groups can be negatively, positively or even neutrally charged according to the relevant solution's pH [5]. Based on several publications, it has been concluded that the desired decomposition of ozone into hydroxyl radicals is favored when the material/catalyst surface is neutrally charged [5,7-12]. Due to its structure, the ozone molecule presents both nucleophilic and electrophilic properties. The (electrophilic) hydrogen atoms and the (nucleophilic) oxygen atoms of hydroxyl groups can simultaneously react with ozone molecules, creating a ring when the hydroxyls are in a natural state. However, this ring is unstable and can easily break down into superoxide radicals $\left(\mathrm{O}_{2}{ }^{\bullet-}\right)$, hence promoting the production of hydroxyl radicals. When hydroxyl groups are positively or negatively charged, the interaction of the surface with ozone molecules decreases and mass transfer between them is inhibited [5].

Wang et al. [7] and Zhu et al. [8] prepared two different magnesium nano-oxides (nano-MgO) with point-of-zero-charge values 10.2 and 7.2, respectively, and used them as catalysts for the removal of phenol and quinolone via the application of a heterogeneous catalytic ozonation process. However, both solid materials showed similar behavior due to their degradation/dissolution in water during the process. The contribution of adsorption to the overall process can be considered as rather negligible. Higher catalytic activity was observed when the catalyst's surface was neutrally charged (i.e., at $\mathrm{pH}=\mathrm{PZC}$ ). In other relevant studies, pumice has been used as a catalyst, either as a raw material or after its modification. Its point-of-zero-charge was 6-7, either as pumice [9] or after iron silicate [10] or iron [11] deposition in its structure. These studies also concluded that at $\mathrm{pH}$ 6-7, pumice presented the best catalytic action because it was neutrally charged. Zhao et al. [12] also tested Cu-cordierite material for the removal of nitrobenzene by catalytic ozonation. Nitrobenzene is a compound that practically cannot be removed by oxidation with molecular ozone, similar to the p-CBA used in this study. Due to the fact that the PZC was 6.94, it exhibited the highest catalytic activity at circa-neutral $\mathrm{pH}$ value, where the surface of the catalyst was also neutrally charged.

Sui et al. [13] used ferric oxy-hydroxide( $\mathrm{FeOOH})$ as a catalyst for the removal of oxalic acid, with the adsorption of this pollutant in the catalyst surface being rather negligible. This research differed because the ozone decomposition and the subsequent production of hydroxyl radicals were found to be enhanced in both the neutral and the positive state of the material, i.e., at neutral and acidic pHs, respectively (PZC = 7.2). Similar results were published by Kermani et al. [14] and Liu et al. [15]; in both cases, positively charged materials showed the highest catalytic activity. Huang et al. [16] claimed that the oxygen groups on the catalyst surface were coupled with bisphenol A via hydrogen bonds, and thus the degradation of ozone was promoted, resulting in increased system efficiency. Through this mechanism, the removal of this micropollutant was increased by increasing the $\mathrm{pH}$ value. 
Furthermore, the hydrophobic molecules of ozone can be attracted by non-polar surfaces, and thus the contact between them is favored [17]. By enhancing the hydrophobic degree of a material, the respective contact can be improved, and the production of hydroxyl radicals can be accelerated. A possible way in which both hydrophobic behavior and point-of-zero-charge (PZC) can be simultaneously increased is the thermal treatment of a material. During thermal treatment, hydrophilic groups, such as hydroxyls, are gradually removed. However, at elevated temperatures (i.e., $>900{ }^{\circ} \mathrm{C}$ ), the surface becomes more hydrophilic due to the decrease in other hydrophobic components, such as in the case of talc siloxanes [18].

The objectives of this work were to study the effects of thermal treatment on the major physicochemical properties of selected natural minerals, acting as potential catalysts in the ozonation process. Subsequently, these properties were correlated with the respective catalytic activity regarding the oxidation of p-CBA by the application of heterogeneous catalytic ozonation. The effect of applied common experimental conditions on their catalytic activity was also investigated. p-CBA was selected as a typical model organic compound because it cannot practically react with ozone molecules $\left(\mathrm{k}_{\mathrm{O} 3}<0.15 \mathrm{M}^{-1} \mathrm{~s}^{-1}\right)$, and it can only be degraded by the presence of hydroxyl radicals $\left(\mathrm{k}_{\bullet} \mathrm{OH}=5 \times 10^{9} \mathrm{M}^{-1} \mathrm{~s}^{-1}\right)$ [19]. Therefore, acceleration of their production can be indirectly estimated by the enhancement of $\mathrm{p}$-CBA removal.

\section{Materials and Methods}

\subsection{Materials}

All the chemicals used in the experiments were of analytical grade. The acetonitrile and phosphoric acid used for p-CBA determination were HPLC-grade and purchased from Sigma-Aldrich (St. Louis, MO, USA). p-CBA was obtained from the same company, and it was used as a model compound at an initial concentration of $4 \mu \mathrm{M}$. All aqueous solutions were prepared in deionized water. For $\mathrm{pH}$ adjustment, $\mathrm{K}_{2} \mathrm{HPO}_{4}$ and $\mathrm{KH}_{2} \mathrm{PO}_{4}$ (Chem-Lab, Zedelgem, Belgium) were used for the preparation of a convenient buffer solution. All the examined solid materials/catalysts were commercially available, and they were pre-treated with ozone before the experiments. Zeolite (Clinoptilolite) from the Metaxades area (Alexandroupoli, Thrace region, Greece)and talc from the Arnissa area (Edessa, Macedonia region, Greece)were calcined at the temperatures $100{ }^{\circ} \mathrm{C}$ (zeolite-1, talc-1), $300{ }^{\circ} \mathrm{C}$ (zeolite-3, talc-3), $600{ }^{\circ} \mathrm{C}$ (zeolite-6, talc-6) and $800{ }^{\circ} \mathrm{C}$ (zeolite-8, talc-8), while kaolin (clay)from the Leukogia area (Drama, Macedonia region, Greece), which was used as a comparison measure, was only calcined at $600{ }^{\circ} \mathrm{C}$ and abbreviated as kaolin-6. Calcination was carried out by raising the temperature from room temperature up to $800^{\circ} \mathrm{C}$ in $2 \mathrm{~h}$, and then the materials were left to cool at room temperature.

\subsection{Experimental Procedures}

The ozonation experiments were performed in batch mode. $\mathrm{O}_{3}$ was generated using a corona discharged $\mathrm{O}_{3}$ generator (Ozonia-Triogen Model TOGC2A) with pure oxygen as the feed gas. The initial p-CBA concentration was $4 \mu \mathrm{M}$, and the $\mathrm{pH}$ values were adjusted between 6 and 8 with the addition of an appropriate amount of $0.005 \mathrm{M} \mathrm{K}_{2} \mathrm{HPO}_{4} / \mathrm{KH}_{2} \mathrm{PO}_{4}$ buffer solution. The initial concentration of $\mathrm{O}_{3}$ was $2 \mathrm{mg} / \mathrm{L}$, based on preliminary experiments. Solid materials/potential catalysts $(0.5 \mathrm{~g} / \mathrm{L})$ were introduced to the dark reaction vessel just before the addition of $\mathrm{O}_{3}$ solution. The catalytic ozonation reaction time was $30 \mathrm{~min}$ for all the experiments, and appropriate samples were received during convenient reaction time intervals, i.e., 1, 3, 15 and $30 \mathrm{~min}$; filtered through $0.45 \mu \mathrm{m}$ membrane filters; and the residual concentrations of $\mathrm{O}_{3}$ and $\mathrm{p}-\mathrm{CBA}$ were determined. The oxidation reaction was stopped by the addition of an appropriate amount of indigo solution. Single ozonation experiments were conducted in the same way but without the addition of a solid/catalyst, while adsorption experiments were performed without the addition of $\mathrm{O}_{3}$. TBA was used as a scavenger to capture the ${ }^{\bullet} \mathrm{OH}$ radicals. The dosage of tert-butyl alcohol (TBA) purchased from Sigma-Aldrich was $0.3 \mathrm{mM}$, calculated based on the equation proposed by Wang et al. [20]. 


\subsection{Analytical Techniques}

Ozone concentrations were determined by the Indigo method [21]. The color change of indigo solution was measured at $600 \mathrm{~nm}$ by a spectrometer (Lange, DR3900). The specific surface area of catalysts was calculated by nitrogen gas adsorption at liquid $\mathrm{N}_{2}$ temperature $(77 \mathrm{~K})$ by using anASAP2020 analyzer, according to the Brunauer-Emmet-Teller (BET) method. Point-of-zero-charge (PZC) values were determined by the immersion technique [22]. Aqueous solutions of $\mathrm{NaNO}_{3}(0.1 \mathrm{M})$ with $\mathrm{pH}$ values ranging from 3 to 11 were prepared, and $0.25 \mathrm{~g}$ of the mineral was added to each solution. Suspensions were equilibrated for $24 \mathrm{~h}$. The PZC value was identified as the $\mathrm{pH}$ value, where the $\mathrm{pH}$ of blank solution is equal to the $\mathrm{pH}$ of mineral suspension. A High-Performance Liquid Chromatography system (Thermo Fisher Scientific, Waltham, MA, USA, HPLC model of UV Spectrum UV2000) was used to determine the residual p-CBA concentration. An Agilent $4.6 \times 250 \mathrm{~mm}$ reversed phase column (model Eclipse Plus C18) was used, and the compound was measured at $254 \mathrm{~nm}$. The mobile phase consisted of acetonitrile and phosphoric acid $(10 \mathrm{mM})$ in the ratio $40: 60 \mathrm{v} / \mathrm{v}$. The $\mathrm{pH}$ of solutions was measured by a pH meter (Jenway, Cole Palmer, UK, model 3540). The mineralogical transformations of thermally treated materials were determined by X-ray diffraction (XRD), using a D8 Advanced instrument (Brucker, Karlsruhe, Germany) operating at $40 \mathrm{~mA}$ and $40 \mathrm{kV}$ with $\mathrm{Cu}$ radiation $(\lambda=1.54 \mathrm{~nm}$ ), the detector LYNXEYE (1D mode) (Brucker Karlsruhe, Germany) were used. The data were collected in the $2 \theta$ range of $5-60^{\circ}$, with increments of $0.010^{\circ}$ and a counting time of $0.1 \mathrm{~s}$ per step for talc and $0.2 \mathrm{~s}$ for zeolite materials. The rotation time was 15 per min for both materials. Thermogravimetric analysis and Differential Thermal Analysis (TG-DTA) were obtained simultaneously by using a Perkin Elmer (Waltham, MA, USA) STA 6000 Thermal Analyzer instrument. The samples were heated from 20 to $900^{\circ} \mathrm{C}$ at a constant rate of $20^{\circ} \mathrm{C} / \mathrm{min}$ in a nitrogen atmosphere (flow $20 \mathrm{~cm}^{3} / \mathrm{min}$ ). Regarding the chemical characterization of minerals, the total content of chemical components was determined by the application of flame atomic adsorption spectroscopy (Perkin Elmer, Waltham, MA, USA, model AAnalyst 800).

\section{Results and Discussion}

\subsection{Catalysts Characterization}

The first part of this study focuses on the effect of thermal treatment on the structure and major physicochemical characteristics of the examined minerals/potential catalysts for the heterogeneous catalytic oxidation process. Zeolite and talc were thermally treated at various temperatures up to $800^{\circ} \mathrm{C}$, while kaolin was only calcined at $600^{\circ} \mathrm{C}$. The respective specific surface area $\left(\mathrm{S}_{\mathrm{BET}}\right)$ of the materials was rather low, e.g., $21 \mathrm{~m}^{2} / \mathrm{g}, 10.5 \mathrm{~m}^{2} / \mathrm{g}$ and $13 \mathrm{~m}^{2} / \mathrm{g}$ for zeolite, talc and kaolin, respectively, and their chemical compositions are shown in Table 1.

Table 1. Chemical composition of examined raw minerals.

\begin{tabular}{ccccccccccc}
\hline Minerals & \multicolumn{9}{c}{ Chemical Composition (\%) } & \multicolumn{2}{c}{$\mathbf{m g} / \mathbf{K g}$} \\
\hline & $\mathbf{S i O}_{\mathbf{2}}$ & $\mathrm{Al}_{\mathbf{2}} \mathbf{O}_{\mathbf{3}}$ & $\mathbf{M g O}$ & $\mathbf{C a O}$ & $\mathbf{N a}_{\mathbf{2}} \mathbf{O}$ & $\mathbf{K}_{\mathbf{2}} \mathbf{O}$ & $\mathbf{F e}_{\mathbf{2}} \mathbf{O}_{\mathbf{3}}$ & $\mathbf{L O I}$ & $\mathbf{N i O}$ & $\mathbf{C r}_{\mathbf{2}} \mathbf{O}_{3}$ \\
\hline Zeolite & 70.5 & 12.1 & 0.58 & 2.91 & 1.45 & 2.82 & 0.67 & $8.9^{\mathrm{a}}$ & $\mathrm{ND}$ & $\mathrm{ND}$ \\
Talc & 65.8 & $\mathrm{ND}$ & 28.6 & 0.01 & 0.01 & 0.04 & 0.73 & $4.6^{\mathrm{b}}$ & 1500 & 20 \\
Kaolin & 50.9 & 33.1 & 0.71 & 0.10 & 0.28 & 1.19 & 0.70 & $12.9^{\mathrm{a}}$ & 120 & $\mathrm{ND}$ \\
$\begin{array}{l}\text { Detection } \\
\text { Limit }\end{array}$ & 0.1 & 0.05 & 0.0005 & 0.004 & 0.001 & 0.002 & 0.01 & 0.1 & 100 & 50 \\
\hline
\end{tabular}

a: Determination at $900{ }^{\circ} \mathrm{C}$ as clarified by TG-DTA. ${ }^{b}$ : Determination at $120{ }^{\circ} \mathrm{C}$, since the loss on ignition of talk is partial at $900{ }^{\circ} \mathrm{C}$ as verified by TG-DTA.

Generally, the mineral structure contains adsorbed and structural water molecules. Under the effect of thermal treatment, the water molecules are removed at different stages. Thermogravimetric Analysis (TGA) was used to monitor the respective weight loss of minerals with the increase in 
temperature. The TGA diagram of zeolite (Figure 1a) shows continuous mass loss during heating up to $700{ }^{\circ} \mathrm{C}$, due to the initial loss of hydroscopic water and the subsequent de-hydroxylation of the crystal lattice. These TGA results suggest that the surface chemistry of zeolite changes with thermal treatment. On the other hand, the diagram of talc (Figure 1b) shows that there was only a small weight loss due to the removal of adsorbed water molecules, even at the higher temperatures. According to Yi et al. [18], the de-hydroxylation of talc only occurs at temperatures higher than $900{ }^{\circ} \mathrm{C}$, which were not part of the present study. The weight loss for talc up to $900{ }^{\circ} \mathrm{C}$ was only $1.3 \%$, while in the same temperature range; zeolite lost $8.9 \%$ of its weight. This is evidence that in talc, no major structural modifications are occurring. During thermal treatment, both minerals only displayed an endothermic effect.
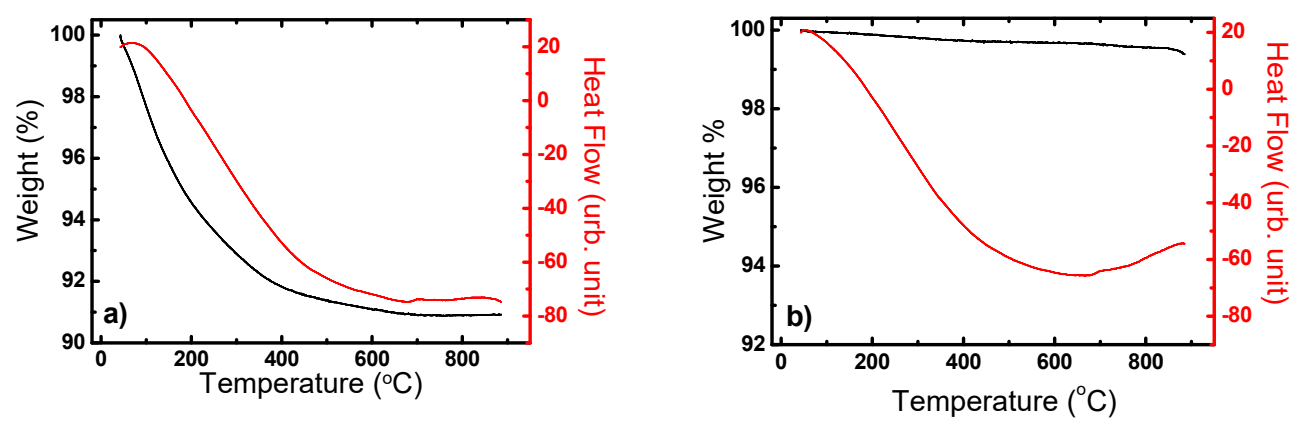

Figure 1. Analysis and Differential Thermal Analysis (TG-DTA) diagrams of (a) zeolite and (b) talc.

The XRD diagrams of raw materials, as well as of the thermally treated samples, are shown in Figure 2. Heating at $900{ }^{\circ} \mathrm{C}$ did not significantly affect talc's mineral structure. On the contrary, the zeolite material collapsed when heated at $600{ }^{\circ} \mathrm{C}$, while at even higher temperatures it was transformed to poorly crystallized phases. Upon heating, zeolites undergo a series of chemical and structural changes until they are eventually largely converted to an amorphous material [23]. Similar observations have been reported by Christidis et al. [24], where a Greek zeolite collapses after heating at $450{ }^{\circ} \mathrm{C}$. Clinoptilolite dehydrates at temperatures up to $300^{\circ} \mathrm{C}$ and dehydroxylates at temperatures up to $800{ }^{\circ} \mathrm{C}$, while at even higher temperatures, it decomposes and transforms into amorphous Al-Si and Si glasses [25].Figure 2a shows the initial raw zeolite containing clinoptilolite (card PDF 01-089-7539) as its major crystalline phase, accompanied by orthoclase (card PDF 01-086-0437), anorthoclase (card PDF 01-075-1634) and quartz (card PDF 01-079-1910). The same structure was presented by the respective calcined material at $300{ }^{\circ} \mathrm{C}$. When zeolite was thermally treated above $500{ }^{\circ} \mathrm{C}$, the characteristic reflections/peaks of clinoptilolite disappeared entirely, and only those of orthoclase, anorthoclase and quartz remained. Figure $2 \mathrm{~b}$ shows the $\mathrm{XRD}$ spectra of talc before and after thermal treatment at temperatures of $300^{\circ} \mathrm{C}, 600^{\circ} \mathrm{C}$ and $800^{\circ} \mathrm{C}$. The diffraction peaks, appearing at $9.44^{\circ}, 18.97^{\circ}, 28,60^{\circ}$ and $48.79^{\circ}$, agree well with the crystal structure of talc, indicating that both the raw material and the thermally treated material used in this work were talc.
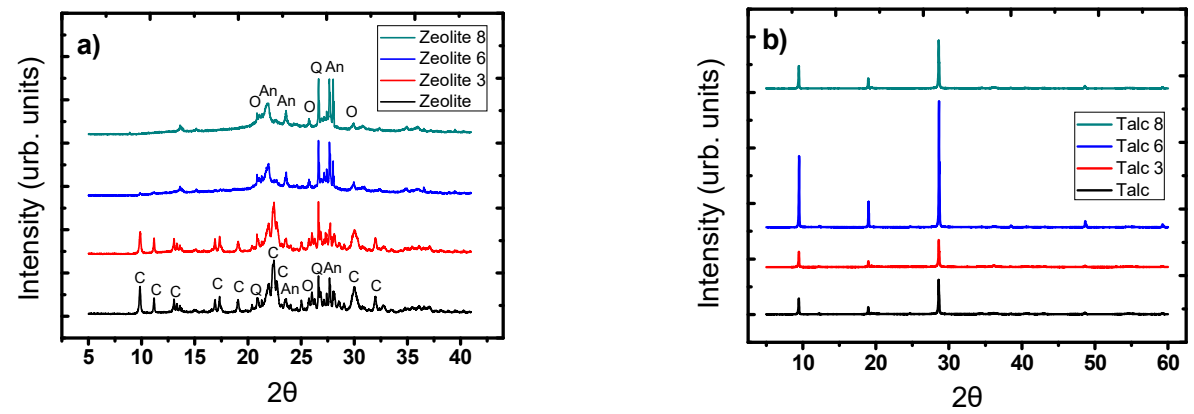

Figure 2. X-ray diffraction (XRD) patterns of raw materials and of thermally treated samples: (a) zeolite and (b) talc. Peaks for (a): C-clinoptilolite, O-orthoclase, An-anorthoclase, Q-quartz. 
The surface charge of any solid material in a solution is based mainly on its PZC value. The PZC of raw kaolin was 3.1, and this value was unchanged up to the temperature of $100^{\circ} \mathrm{C}$. After that, there was an increase in the PZC value, probably due to dehydroxylation. At $800^{\circ} \mathrm{C}$, the PZC increased to 4.4, probably due to the formation of meta-kaolin, as Torres Sánchez and Tavani observed [6]. Its structural water began to be removed at $500^{\circ} \mathrm{C}$ and completed at $600^{\circ} \mathrm{C}$, as verified by the weight loss in Supplementary Materials Figure S1. In the same temperature range, the PZC of kaolin increased sharply. The PZC of zeolite and of talc were also found to increase but to a lower extent. The PZC of raw zeolite and of talc were 6.8 and 5.9 , and after calcination at $800{ }^{\circ} \mathrm{C}$, they increased by 0.4 and 0.8 units, respectively. Changes to the values of PZC depend on the heating temperature of each material and are shown in Figure 3.

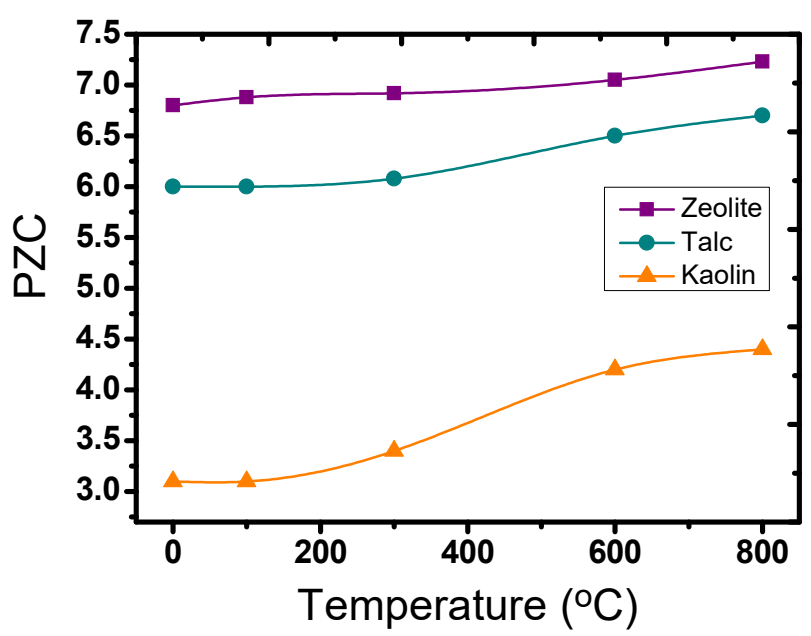

Figure 3. Point-of-zero-charge (PZC) of zeolite, talc and kaolin after calcination treatment in the temperature range $100-800{ }^{\circ} \mathrm{C}$.

One of the main mechanisms regarding the formation of charges on the surface of an oxide in aqueous media is the sorption of metal hydrolytic complexes derived from the hydrolysis of solid material [26]. Therefore, the differences in PZC values in the experiments were provoked by the formation of these hydro-complexes on the surface of minerals. This is in accordance with the results of other relevant studies on several oxides [6,27]. Furthermore, Stanković et al. [28] have observed that the PZC of a hydrous oxide was found to depend more on the hydration degree than on the crystal structure of the oxide, and generally the $\mathrm{PZC}$ value shifts towards the alkaline $\mathrm{pH}$ region during the dehydration process.

\subsection{Catalytic Activity of the Examined Natural Minerals}

In this study, the catalytic activity of three natural minerals was investigated before and after their thermal treatment, regarding the application of heterogeneous catalytic ozonation for the destruction by oxidation of p-CBA. All these materials showed rather low uptake (adsorption) capacities independently of calcination temperature (Table S1). Therefore, none of them can be characterized as an efficient adsorbent material, at least for the examined micropollutant. The absorption capacity is illustrated in Figure 1 for the negative values of time.

The catalytic activity of these solids was evaluated through p-CBA removal efficiency in the ozonation process, and the obtained results of heterogeneous catalytic ozonation were compared with those of single ozonation application. The red, dashed line in Figure 4 and Figures 6-8 represents the p-CBA analytical detection limit. All these materials were found to enhance the decomposition of ozone when compared with single ozonation (Figure S2), but not all of them were found to present catalytic activity. Catalytic activity means the acceleration of p-CBA removal due to the enhancement of hydroxyl radical production. Raw zeolite and talc can be considered as catalysts, while kaolin, 
neither before or after its calcination, was found to present any catalytic activity (Figure 4). Kaolin is a material with PZC 3.1. After thermal treatment, the PZC of kaolin increased to 4.7. Therefore, in both forms, it is a strongly negatively charged solid in the neutral $\mathrm{pH}$ range, where most of the experiments were performed. Ozone molecules tend to approach neutrally charged and non-polar surfaces more effectively, enhancing their decomposition into hydroxyl radicals when coming into contact $[5,7-9,29]$. Raw talc (with PZC 5.9) presents lower catalytic activity than talc-8, which has PZC equal to 6.5 and a more hydrophobic surface. The catalytic activity of neutrally charged raw zeolite was enhanced through the application of thermal treatment, because the PZC and the hydrophobicity of the material increased. The best relevant performance was presented by the zeolite-8, where the efficiency of treatment process was $98.5 \%$ even from the first min of reaction/oxidation time. All zeolites showed higher catalytic activity even than talc- 8 because they were neutrally charged, while talc- 8 with PZC 6.5 was slightly negatively charged throughout the oxidation process. However, among the talc materials, talc- 8 was optimum and removed $95.5 \%$ of p-CBA, even from the first min of oxidation.
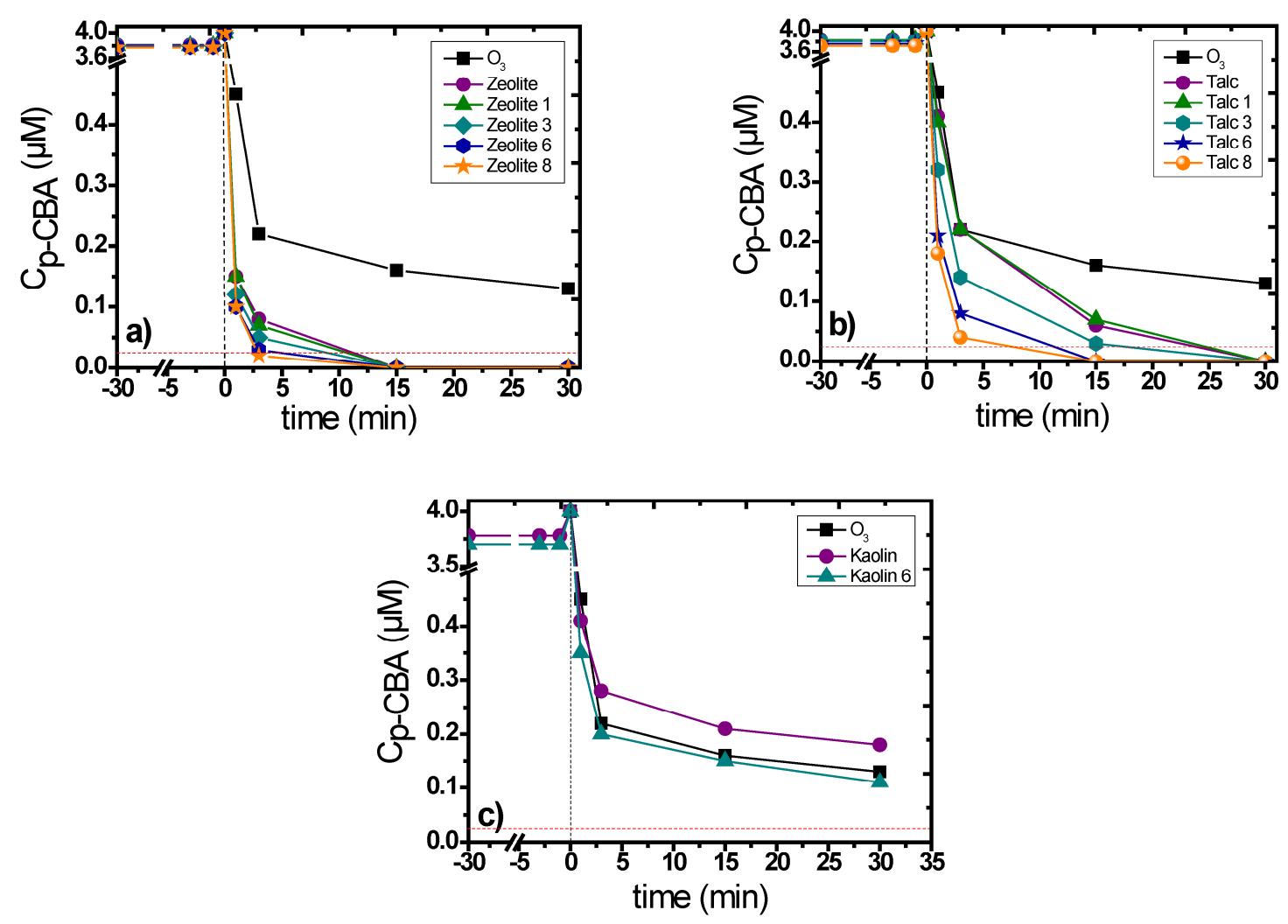

Figure 4. Effect of calcination temperature on the catalytic activity of examined natural minerals: (a) zeolite, (b) talc, and (c) kaolin; experimental conditions: $\mathrm{C}_{\mathrm{p}-\mathrm{CBA}} 4 \mu \mathrm{M}, \mathrm{C}_{\mathrm{O} 3} 2 \mathrm{mg} / \mathrm{L}, \mathrm{C}_{\text {cat. }} 0.5 \mathrm{~g} / \mathrm{L}, \mathrm{pH}$ 7 , temperature $23 \pm 2{ }^{\circ} \mathrm{C}$.

The high correlation between PZC values and the efficiency of the heterogeneous catalytic ozonation process is shown in Figure 5 for the cases of thermally treated zeolite and talc. An almost linear response was observed between PZC values and their respective catalytic ozonation efficiency. Correlation was performed considering the values from the first min of reaction/oxidation time because differences in respective performances at that early oxidation time were more pronounced. The difference in the efficiency between talc and talc- 8 was higher when compared with relevant observations in the case of zeolite, because the increase of the PZC value was greater for talc (Figure 3). 

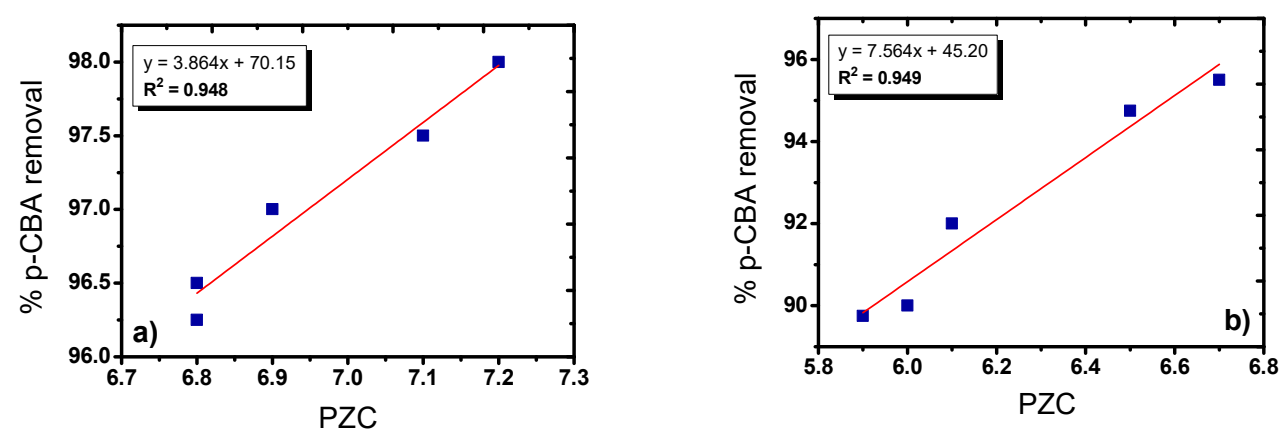

Figure 5. Correlation between PZC values (as obtained from raw and thermally treated mineral samples) and the respective catalytic efficiency calcinated materials, considering the first min of reaction/oxidation:(a) zeolite and (b) talc; experimental conditions: $\mathrm{C}_{\mathrm{p}-\mathrm{CBA}} 4 \mu \mathrm{M}, \mathrm{C}_{\mathrm{O} 3} 2 \mathrm{mg} / \mathrm{L}$, $\mathrm{C}_{\text {cat. }} 0.5 \mathrm{~g} / \mathrm{L}, \mathrm{pH} 7$, temperature $23 \pm 2{ }^{\circ} \mathrm{C}$.

In addition to removing/oxidizing p-CBA, other evidence that the catalytic ozonation process was based on the formation of the radicals' mechanism was the efficiency of the system in the presence of TBA. TBA is a known hydroxyl radical scavenger with a high reaction rate constant with hydroxyl radicals equal to $5 \times 10^{8} \mathrm{M}^{-1} \mathrm{~s}^{-1}$ [20]. Figure 6 shows the efficiency of single and catalytic ozonation in the absence and presence of TBA, when zeolite- 6 and talc- 6 were used as catalysts. When TBA was added to the treatment system, the removal of p-CBA was $6.3 \%, 12.5 \%$ and $9.5 \%$ with the application of single ozonation or by the addition of zeolite and talk, respectively, after 30 min of oxidation time. The inhibition effect within the first $3 \mathrm{~min}$ of the relevant scavenging reaction was estimated at $94.5 \%, 99.3 \%$ and $99.5 \%$, respectively. The presence of TBA also reduced the decomposition of ozone in all oxidation reactions (Figure S3). It is also worth noting that the application of higher ozone concentrations could not be beneficial in the relevant systems because ozone does not practically react with p-CBA $\left(\mathrm{k}_{\mathrm{O} 3}<0.15 \mathrm{M}^{-1} \mathrm{~s}^{-1}\right)$ [19].

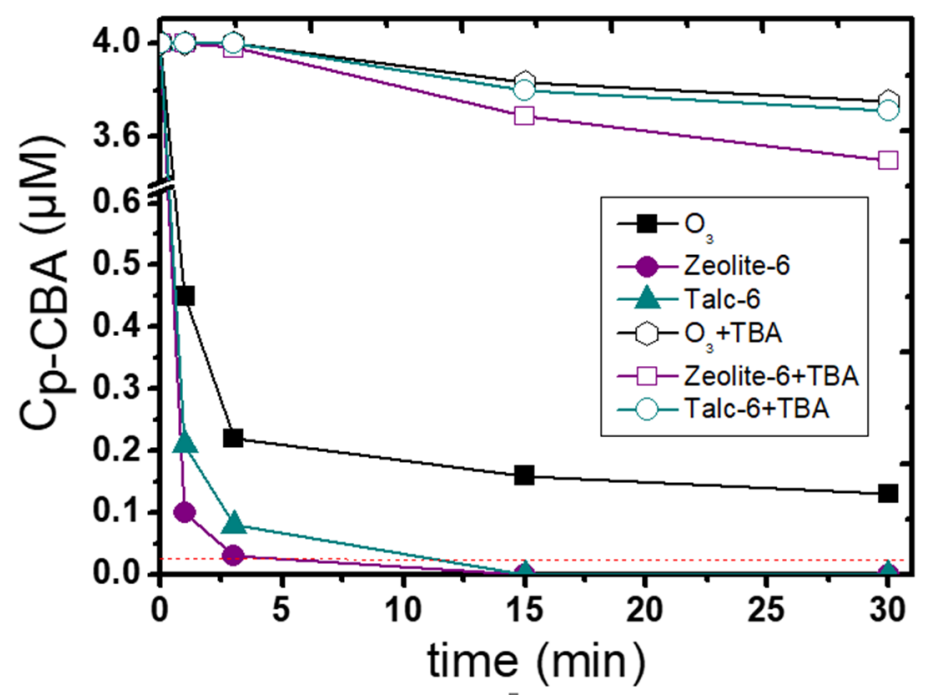

Figure 6. Effect of tert-butyl alcohol (TBA) in the removal of p-CBA during the application of single and catalytic ozonation processes; experimental conditions: $\mathrm{C}_{\mathrm{p}-\mathrm{CBA}} 4 \mu \mathrm{M}, \mathrm{C}_{\mathrm{TBA}} 0.4 \mathrm{mM}, \mathrm{C}_{\mathrm{O} 3} 2 \mathrm{mg} / \mathrm{L}$, $\mathrm{C}_{\text {cat. }} 0.5 \mathrm{~g} / \mathrm{L}, \mathrm{pH} 7$, temperature $23 \pm 2{ }^{\circ} \mathrm{C}$.

\subsection{Influence of the Main Experimental Parameters on the Removal of $p-C B A$}

There are several factors that can affect the efficiency of the heterogeneous catalytic ozonation process. The most important among them are $\mathrm{pH}$ and temperature, which influence the stability of ozone in water [4]. The influence of experimental conditions was studied for the examined materials, 
especially in the cases of zeolite- 6 and talc- 6 , calcined at $600{ }^{\circ} \mathrm{C}$. The difference in the respective efficiencies between materials calcined at temperatures $600^{\circ} \mathrm{C}$ and $800^{\circ} \mathrm{C}$ was rather negligible. Also, the moderate calcination temperature of $600^{\circ} \mathrm{C}$ is more practically feasible and less costly.

$\mathrm{pH}$ value is a very important aspect of the ozonation process because it highly influences the ozone decomposition and the subsequent production of hydroxyl radicals. As the $\mathrm{pH}$ raises, the decomposition of ozone accelerates (Figure S4). Figure 7 shows p-CBA removal when zeolite- 6 and talc- 6 were added to the system as catalysts for $\mathrm{pH}$ values 6, 7 and 8 . As expected, higher pollutant degradation was observed at $\mathrm{pH} 8$, independently of the catalyst that was added to the oxidation system. At pH 8, p-CBA was almost totally removed, already within the third min of oxidation time. In contrast, at $\mathrm{pH} 6$ and for the same time (third $\mathrm{min}$ ) the p-CBA removal was $91.7 \%$ and $93 \%$ forzeolite- 6 and talc- 6 , respectively. Less efficiency at this (slightly acidic) $\mathrm{pH}$ value could be attributed to the lower production of hydroxyl radicals, since p-CBA cannot practically react with ozone molecules, only hydroxyl radicals. Neutrally charged talc and slightly negatively charged zeolite were found to degrade p-CBA almost entirely after 15 min of reaction/oxidation time in $\mathrm{pH}$ range 6-8.
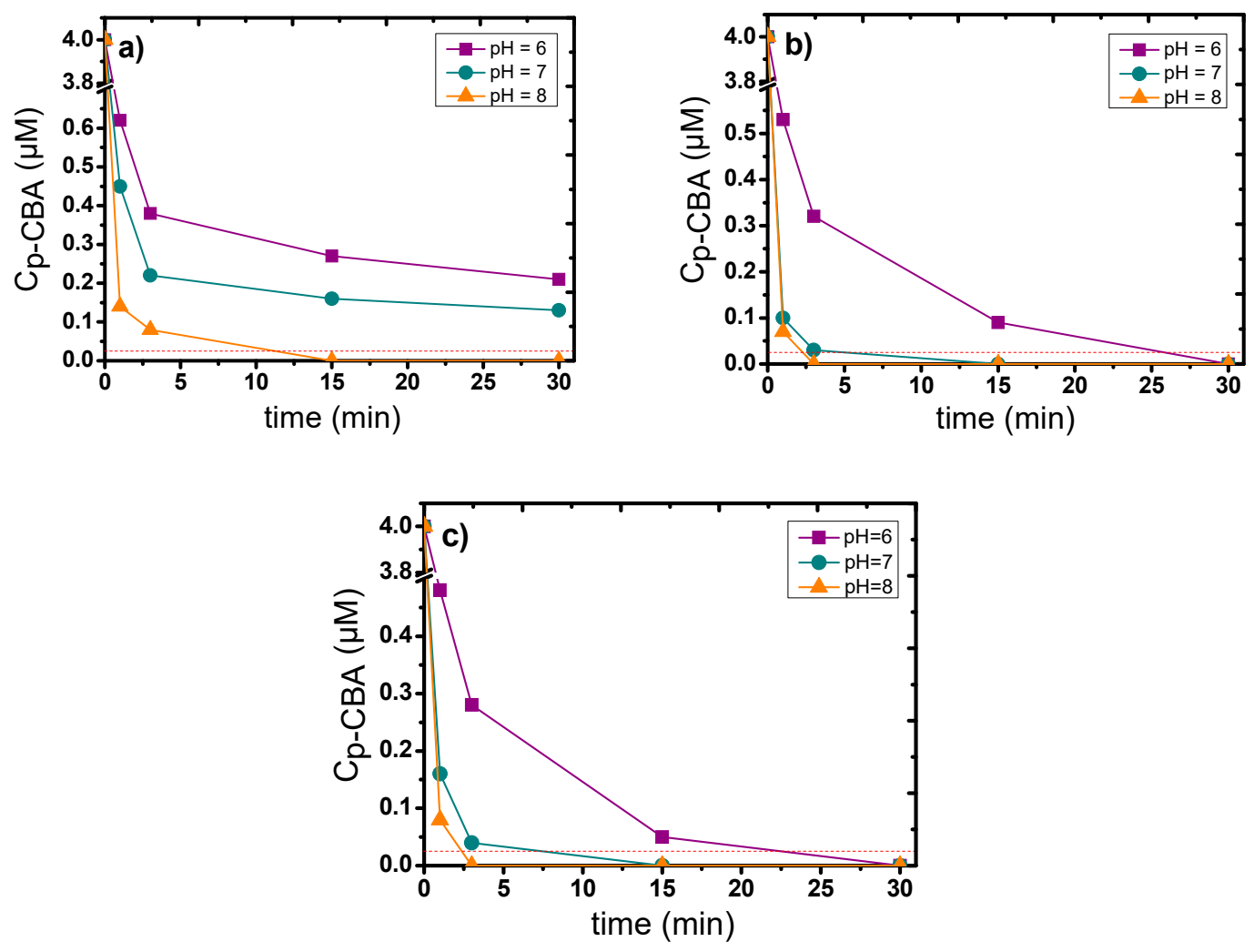

Figure 7. Influence of $\mathrm{pH}$ values on $\mathrm{p}-\mathrm{CBA}$ removal by the application of (a) single ozonation and heterogeneous catalytic ozonation, using qualified catalysts:(b) Zeolite- 6 and(c) Talc-6; experimental conditions: $\mathrm{C}_{\mathrm{p}-\mathrm{CBA}} 4 \mu \mathrm{M}, \mathrm{C}_{\mathrm{O} 3} 2 \mathrm{mg} / \mathrm{L}, \mathrm{C}_{\text {cat. }} 0.5 \mathrm{~g} / \mathrm{L}$, temperature $23 \pm 2{ }^{\circ} \mathrm{C}$.

Furthermore, ozone molecules are more stable in an aqueous solution at lower temperatures; therefore, ozone decomposition reactions and the respective production of radicals are slower. For this reason, the removal efficiency of micropollutants was decreased by decreasing the solution temperature (Figure 8). At $15{ }^{\circ} \mathrm{C}$, the production of hydroxyl radicals was limited, and the p-CBA was removed by $93.2 \%$ and $82 \%$ with the addition of zeolite- 6 and talc- 6 , respectively, after $30 \mathrm{~min}$ of reaction/oxidation time. According to the van't Hoff rule, an increase in temperature of $10^{\circ} \mathrm{C}$ will double the reaction kinetics rate. Although a rise in temperature can increase ozone decomposition and chemical reaction rates, it simultaneously decreases the dissolved ozone concentration in water [30]. Table 2 shows the escape of ozone in the gas phase at various temperatures under the assumption that the equilibrium of 
ozone in the gas/aqueous phase would be achieved quickly, resulting in lower ozone participation at the oxidation/reaction stage. These calculations are based on Wang et al.'s study [31] and are presented in the supplementary text S1. However, even in such an extreme theoretical hypothesis, ozone behavior depends on the temperature of the reaction. An increase in the temperature of an aqueous solution accelerates the escape of ozone in the gaseous phase (Table 2). Thus, increasing the reaction kinetic for $\mathrm{p}$-CBA degradation by increasing the temperature from $15^{\circ} \mathrm{C}$ to $25^{\circ} \mathrm{C}$ exceeds the corresponding increase of ozone escape in the gaseous phase, while at $35^{\circ} \mathrm{C}$ the higher escape of ozone in the gaseous phase results in lower degradation of p-CBA. Furthermore, increasing the temperature generally decreases the adsorption of micropollutants (Table S2) on the surface of catalysts, reducing the efficiency of heterogeneous catalytic ozonation reactions [30]. The actual ozone concentration during the experiments as a function of temperature is shown in supplementary Figure S5.
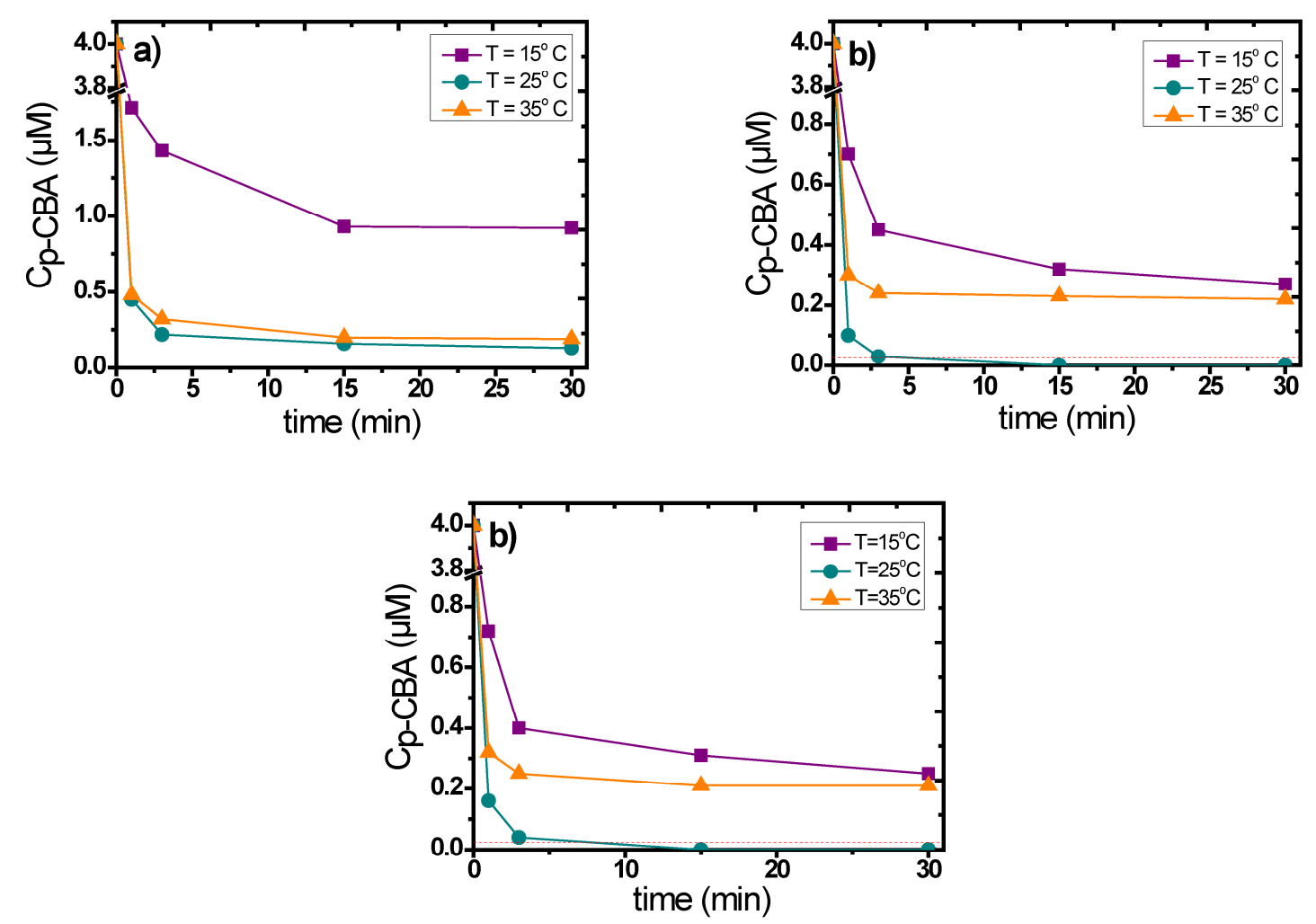

Figure 8. Influence of temperature on the removal of p-CBA by the application of (a) single ozonation and heterogeneous catalytic ozonation using optimum defined catalysts: (b) zeolite- 6 and (c) Talc-6; experimental conditions: $\mathrm{C}_{\mathrm{p}-\mathrm{CBA}} 4 \mu \mathrm{M}, \mathrm{C}_{\mathrm{O} 3} 2 \mathrm{mg} / \mathrm{L}, \mathrm{C}_{\text {cat. }} .0 .5 \mathrm{~g} / \mathrm{L}, \mathrm{pH} 7$.

Table 2. Theoretically calculated ozone escape from aqueous solution into air for various temperatures during the reaction/oxidation stage.

\begin{tabular}{cccc}
\hline & \multicolumn{3}{c}{ Ozone Escape } \\
\hline Reaction Time (Min) & $\mathbf{1 5}{ }^{\circ} \mathbf{C}$ & $\mathbf{2 5}{ }^{\circ} \mathbf{C}$ & $35{ }^{\circ} \mathbf{C}$ \\
\hline 0.1 & $3.8 \%$ & $4.7 \%$ & $5.6 \%$ \\
1 & $5.8 \%$ & $7 \%$ & $8.3 \%$ \\
3 & $7.7 \%$ & $9.4 \%$ & $11.1 \%$ \\
15 & $9.6 \%$ & $11.7 \%$ & $13.9 \%$ \\
30 & $11.5 \%$ & $14.1 \%$ & $16.7 \%$ \\
\hline
\end{tabular}

In this study, the optimum temperature for the removal of pollutants by the application of heterogeneous catalytic ozonation was $25^{\circ} \mathrm{C}$. After $3 \mathrm{~min}$ of reaction time, the concentration of $\mathrm{p}$-CBA was $34.4 \mu \mathrm{g} / \mathrm{L}, 4.7 \mu \mathrm{g} / \mathrm{L}$ and $6.3 \mu \mathrm{g} / \mathrm{L}$ in the $\mathrm{O}_{3}$, zeolite- $6 / \mathrm{O}_{3}$ and talc- $6 / \mathrm{O}_{3}$ oxidation processes. When 
the temperature was raised to $35^{\circ} \mathrm{C}$, the removal efficiency for the same duration/oxidation time decreased by $31.3 \%, 87.5 \%$ and $68 \%$, respectively. This reduction was mainly attributed to lower adsorption capacity (Table S2), as well as the increase of ozone escape towards the gas/air phase. Similar observations were also reported by Luo et al., 2018 [32].

\section{Conclusions}

In this study, the catalytic activity of three natural minerals, selected after preliminary screening experiments, was examined after thermal pre-treatment in the temperature range between $100^{\circ}$ and $800^{\circ} \mathrm{C}$, during the application of heterogeneous catalytic ozonation process for the removal of p-CBA. The PZC of these solid materials was increased by thermal treatment. A PZC value around the $\mathrm{pH}$ value of the solution favors the efficient contact of ozone molecules with the catalyst surface and therefore can accelerate its decomposition, leading to the production of $\bullet \mathrm{OH}$ radicals.

For the $\mathrm{PZC}$ values of the examined minerals approaching the circa-neutral solution $\mathrm{pH}$ (i.e., for the neutrally charged solids), the efficiency of the oxidation process increased. At $\mathrm{pH} 7$ and $25^{\circ} \mathrm{C}$, the negatively charged kaolin surface showed no catalytic activity. Under the same conditions, talc (as a raw material with PZC 5.9) was found to present moderate catalytic activity, but after its calcination at $800{ }^{\circ} \mathrm{C}$, performance increased by $56 \%$ even after the first min of oxidation time because the respective PZC value increased to 6.5. Furthermore, neutrally charged raw zeolite was found to efficiently remove $\mathrm{p}-\mathrm{CBA}$ and increase the PZC value (to 7.2) after calcination further improved its performance.

The higher production of ${ }^{\bullet} \mathrm{OH}$ and the subsequent higher efficiency of the oxidation process were found to be closely related to the neutrally charged surfaces of solid materials, acting as catalysts that can more effectively attract ozone molecules. The optimum conditions for all the examined parameters were a $\mathrm{pH}$ value of 8 and a temperature of $25^{\circ} \mathrm{C}$. Where the dissolution of ozone in the aqueous phase was satisfactory, the decomposition of ozone was fast and the production of ${ }^{\bullet} \mathrm{OH}$ radicals was high. The removal of $\mathrm{p}-\mathrm{CBA}$ was based on the mechanism of radical production and was verified by the addition of TBA, which substantially reduced the efficiency of the treatment system (in the range of $94.5 \%$ in the case of single ozonation).

Supplementary Materials: The following are available online at http://www.mdpi.com/2071-1050/12/24/10503/s1, Figure S1: (a) TG-DTA and (b) XRD diagram of kaolin; Peaks for K: Kaolin, I: Illite. Figure S2: Influence of the thermal pre-treatment on ozone decomposition in comparison to single ozonation: (a) zeolite, (b) talc, and (c) kaolin. Experimental conditions: ozone concentration $2 \mathrm{mg} / \mathrm{L}$, catalyst concentration $0.5 \mathrm{~g} / \mathrm{L}, \mathrm{p}-\mathrm{CBA}$ concentration $4 \mu \mathrm{M}, \mathrm{pH} 7$ and temperature $23 \pm 2{ }^{\circ} \mathrm{C}$. Figure S3: Effect of TBA on ozone decomposition in the catalytic ozonation systems, as compared to singleozonation. Experimental conditions: ozone concentration $2 \mathrm{mg} / \mathrm{L}$, catalyst concentration $0.5 \mathrm{~g} / \mathrm{L}, \mathrm{p}-\mathrm{CBA}$ concentration $4 \mu \mathrm{M}$, TBA concentration $0.4 \mathrm{mM}, \mathrm{pH} 7$ and temperature 23 $\pm 2{ }^{\circ} \mathrm{C}$. Figure S4: Effect of $\mathrm{pH}$ value on the decomposition of ozone; (a) Single ozonation, (b) zeolite- 6 , and (c) talc-6. Experimental conditions: ozone concentration $2 \mathrm{mg} / \mathrm{L}$, catalyst concentration $0.5 \mathrm{~g} / \mathrm{L}, \mathrm{p}$-CBA concentration $4 \mu \mathrm{M}$ and temperature $23 \pm 2{ }^{\circ} \mathrm{C}$. Figure S5: Effect of temperature on ozone decomposition; (a) Single ozonation, (b) zeolite-6, and (c) talc-6. Experimental conditions: ozone concentration $2 \mathrm{mg} / \mathrm{L}$, catalyst concentration $0.5 \mathrm{~g} / \mathrm{L}$, p-CBA concentration $4 \mu \mathrm{M}$ and $\mathrm{pH}$ 7. Table S1: Adsorption capacity of natural minerals thermally pre-treated at various temperatures for the case of p-CBA removal. Experimental conditions: catalyst concentration $0.5 \mathrm{~g} / \mathrm{L}$, p-CBA concentration $4 \mu \mathrm{M}, \mathrm{pH} 7$, temperature $23 \pm 2{ }^{\circ} \mathrm{C}$ and adsorption time $30 \mathrm{~min}$. Table S2: Adsorption capacity of zeolite-6, and talc- 6 for the case of p-CBA removal at various temperatures. Experimental conditions: catalyst concentration: $0.5 \mathrm{~g} / \mathrm{L}, \mathrm{p}$-CBA concentration: $4 \mu \mathrm{M}, \mathrm{pH}: 7$ and adsorption time $30 \mathrm{~min}$. Text S1: Example of calculation, regarding the theoretical escape of ozone from the water during the experiment.

Author Contributions: Conceptualization, S.P., M.M. and A.Z.; methodology, S.P. and M.M.; validation, S.P., M.M. and A.Z.; formal analysis, S.P., E.K. and K.K.; investigation, S.P. and K.K.; resources, M.M. and A.Z.; data curation, S.P. and E.K.; writing — original draft preparation, S.P.; writing —review and editing, E.K., M.M. and A.Z.; visualization, S.P.; supervision, M.M. and A.Z.; project administration, A.Z.; funding acquisition, A.Z. All authors have read and agreed to the published version of the manuscript. 
Funding: This research has been co-financed by the European Union and Greek national funds through the Operational Program Competitiveness, Entrepreneurship and Innovation, under the call RESEACH-CREATEINNOVATE (project code: T1EDK-02397).
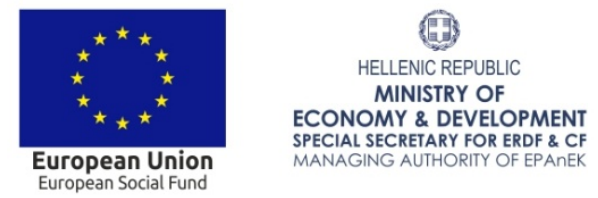

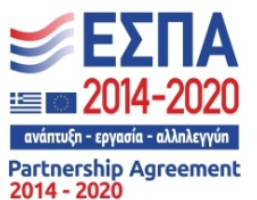

Partnership $2014-2020$
201

Co-financed by Greece and the European Union

Conflicts of Interest: The authors declare no conflict of interest.

\section{References}

1. Cuerda-Correa, E.M.; Alexandre-Franco, M.F.; Fernández-González, C. Advanced Oxidation Processes for the Removal of Antibiotics from Water. An Overview. Water 2019, 12, 102. [CrossRef]

2. Stamm, C.; Räsänen, K.; Burdon, F.J.; Altermatt, F.; Jokela, J.; Joss, A.; Ackermann, M.; Eggen, R.I.L. Unravelling the Impacts of Micropollutants in Aquatic Ecosystems. In Advances in Ecological Research; Elsevier: Amsterdam, The Netherlands, 2016; Volume 55, pp. 183-223. [CrossRef]

3. Rogowska, J.; Cieszynska-Semenowicz, M.; Ratajczyk, W.; Wolska, L. Micropollutants in Treated Wastewater. Ambio 2020, 49, 487-503. [CrossRef] [PubMed]

4. Nawrocki, J.; Kasprzyk-Hordern, B. The Efficiency and Mechanisms of Catalytic Ozonation. Appl. Catal. B Environ. 2010, 99, 27-42. [CrossRef]

5. Gao, G.; Kang, J.; Shen, J.; Chen, Z.; Chu, W. Heterogeneous Catalytic Ozonation of Sulfamethoxazole in Aqueous Solution over Composite Iron-Manganese Silicate Oxide. Ozone Sci. Eng. 2017, 39, $24-32$. [CrossRef]

6. Torres Sánchez, R.M.; Tavani, E.L. Temperature Effects on the Point of Zero Charge and Isoelectric Point of a Red Soil Rich in Kaolinite and Iron Minerals. J. Therm. Anal. 1994, 41, 1129-1139. [CrossRef]

7. Wang, B.; Xiong, X.; Ren, H.; Huang, Z. Preparation of MgO Nanocrystals and Catalytic Mechanism on Phenol Ozonation. RSC Adv. 2017, 7, 43464-43473. [CrossRef]

8. Zhu, H.; Ma, W.; Han, H.; Han, Y.; Ma, W. Catalytic Ozonation of Quinoline Using Nano-MgO: Efficacy, Pathways, Mechanisms and Its Application to Real Biologically Pretreated Coal Gasification Wastewater. Chem. Eng. J. 2017, 327, 91-99. [CrossRef]

9. Yuan, L.; Shen, J.; Chen, Z.; Liu, Y. Pumice-Catalyzed Ozonation Degradation of p-Chloronitrobenzene in Aqueous Solution. Appl. Catal. B Environ. 2012, 117-118, 414-419. [CrossRef]

10. Gao, G.; Shen, J.; Chu, W.; Chen, Z.; Yuan, L. Mechanism of Enhanced Diclofenac Mineralization by Catalytic Ozonation over Iron Silicate-Loaded Pumice. Sep. Purif. Technol. 2017, 173, 55-62. [CrossRef]

11. Yuan, L.; Shen, J.; Chen, Z.; Guan, X. Role of Fe/Pumice Composition and Structure in Promoting Ozonation Reactions. Appl. Catal. B Environ. 2016, 180, 707-714. [CrossRef]

12. Zhao, L.; Sun, Z.; Ma, J.; Liu, H. Enhancement Mechanism of Heterogeneous Catalytic Ozonation by Cordierite-Supported Copper for the Degradation of Nitro benzene in Aqueous Solution. Environ. Sci. Technol. 2009, 43, 2047-2053. [CrossRef] [PubMed]

13. Sui, M.; Sheng, L.; Lu, K.; Tian, F. FeOOH Catalytic Ozonation of Oxalic Acid and the Effect of Phosphate Binding on Its Catalytic Activity. Appl. Catal. B Environ. 2010, 96, 94-100. [CrossRef]

14. Kermani, M.; Kakavandi, B.; Farzadkia, M.; Esrafili, A.; Jokandan, S.F.; Shahsavani, A. Catalytic Ozonation of High Concentrations of Catecholover $\mathrm{TiO}_{2} @ \mathrm{Fe}_{3} \mathrm{O}_{4}$ Magnetic Core-Shell Nanocatalyst: Optimization, Toxicity and Degradation Pathway Studies. J. Clean. Prod. 2018, 192, 597-607. [CrossRef]

15. Liu, Z.-Q.; Tu, J.; Wang, Q.; Cui, Y.-H.; Zhang, L.; Wu, X.; Zhang, B.; Ma, J. Catalytic Ozonation of Diethyl Phthalate in Aqueous Solution Using Graphite Supported Zinc Oxide. Sep. Purif. Technol. 2018, 200, 51-58. [CrossRef]

16. Huang, Y.; Xu, W.; Hu, L.; Zeng, J.; He, C.; Tan, X.; He, Z.; Zhang, Q.; Shu, D. Combined Adsorption and Catalytic Ozonation for Removal of Endocrine Disrupting Compounds over MWCNTs/ $/ \mathrm{Fe}_{3} \mathrm{O}_{4}$ Composites. Catal. Today 2017, 297, 143-150. [CrossRef] 
17. Psaltou, S.; Karapatis, A.; Mitrakas, M.; Zouboulis, A. The Role of Metal Ions on P-CBA Degradation by Catalytic Ozonation. J. Environ. Chem. Eng. 2019, 7, 103324. [CrossRef]

18. Yi, H.; Zhao, Y.; Liu, Y.; Wang, W.; Song, S.; Liu, C.; Li, H.; Zhan, W.; Liu, X. A Novel Method for Surface Wettability Modification of Talc through Thermal Treatment. Appl. Clay Sci. 2019, 176, 21-28. [CrossRef]

19. Aljibouri, A.K.H.; Wu, J.; Upreti, S.R. Heterogeneous Catalytic Ozonation of Naphthenic Acids in Water. Can. J. Chem. Eng. 2019, 97, 67-73. [CrossRef]

20. Wang, Q.; Yang, Z.; Chai, B.; Cheng, S.; Lu, X.; Bai, X. Heterogeneous Catalytic Ozonation of Natural Organic Matter with Goethite, Cerium Oxide and Magnesium Oxide. RSC Adv. 2016, 6, 14730-14740. [CrossRef]

21. Clesceri, S.L.; Greenberg, E.A.; Trussell, R.R. Inorganic Nonmetals, in Standard Methods for Examination of Water and Wastewater, 17th ed.; American Public Health Association: Washington, DC, USA, 1989.

22. Bourikas, K.; Vakros, J.; Kordulis, C.; Lycourghiotis, A. Potentiometric Mass Titrations: Experimental and Theoretical Establishment of a New Technique for Determining the Point of Zero Charge (PZC) of Metal (Hydr) Oxides. J. Phys. Chem. B 2003, 107, 9441-9451. [CrossRef]

23. Perraki, T.; Kakali, G.; Kontori, E. Characterization and Pozzolanic Activity of Thermally Treated Zeolite. J. Anal. Calorim. 2005, 82, 109-113. [CrossRef]

24. Christidis, G. Chemical and Thermal Modification of Natural HEU-Type Zeolitic Materials from Armenia, Georgia and Greece. Appl. Clay Sci. 2003, 24,79-91. [CrossRef]

25. Palenta, T.; Fuhrmann, S.; Greaves, G.N.; Schwieger, W.; Wondraczek, L. Thermal collapse and hierarchy of polymorphs in a faujasite-type zeolite and its analogous melt-quenched glass. J. Chem. Phys. 2015, 142, 084503. [CrossRef] [PubMed]

26. Parks, G.A. The Isoelectric Points of Solid Oxides, Solid Hydroxides, and Aqueous Hydroxo Complex Systems. Chem. Rev. 1965, 65, 177-198. [CrossRef]

27. Ardizzone, S.; Daghetti, A.; Franceschi, L.; Trasatti, S. The Point of Zero Charge of Hydrous $\mathrm{RuO}_{2}$. Colloids Surf. 1989, 35, 85-96. [CrossRef]

28. Stankovic, J.; Milonjic, S.; Zec, S. The Influence of Chemical and Thermal Treatment on the Point of Zero Charge of Hydrous Zirconium Oxide. J. Serb. Chem. Soc. 2013, 78, 987-995. [CrossRef]

29. Kasprzyk-Hordern, B.; Dabrowska, A.; Świetlik, J.; Nawrocki, J. Ozonation Enhancement with Nonpolar Bonded Alumina Phases. Ozone Sci. Eng. 2004, 26, 367-380. [CrossRef]

30. Gottschalk, C.; Libra, J.A.; Saupe, A. Ozonation of Water and Waste Water. In A Practical Guide to Understanding Ozone and Its Application; Wiley-VCH: Weinheim, Germany, 2010.

31. Wang, D.; Xu, H.; Ma, J.; Lu, X.; Qi, J.; Song, S. Strong Promoted Catalytic Ozonation of Atrazine at Low Temperature Using Tourmaline as Catalyst: Influencing Factors, Reaction Mechanisms and Pathways. Chem. Eng. J. 2018, 354, 113-125. [CrossRef]

32. Luo, L.; Zou, D.; Lu, D.; Yu, F.; Xin, B.; Ma, J. Study of Catalytic Ozonation for Tetracycline Hydrochloride Degradation in Water by Silicate Ore Supported $\mathrm{Co}_{3} \mathrm{O}_{4}$. RSC Adv. 2018, 8, 41109-41116. [CrossRef]

Publisher's Note: MDPI stays neutral with regard to jurisdictional claims in published maps and institutional affiliations.

(C) 2020 by the authors. Licensee MDPI, Basel, Switzerland. This article is an open access article distributed under the terms and conditions of the Creative Commons Attribution (CC BY) license (http://creativecommons.org/licenses/by/4.0/). 